\title{
Economical Suppression of Agricultural Business and Governmental Policies
}

\author{
Nikhil S. Mane ${ }^{1}$, Suhas N. Ankalkhope ${ }^{2}$, Sandesh S. Awati ${ }^{3}$ and Siddhanath Nishandar ${ }^{4}$ \\ ${ }^{1,2 \& 3}$ Assistant Professor, Padmbhooshan Vasantraodada Patil Institute of Technology, Budhgaon, Maharashtra, India \\ ${ }^{4}$ Assistant Professor, Annasaheb Dange College of Engineering \& Technology, Ashta, Madhya Pradesh, India \\ E-Mail: manenikhil24@gmail.com
}

\begin{abstract}
The agricultural sector has always been an important part of Indian economy. Even though in Indian society farmer and farming has a sacred place but the economic conditions and social status of farmer has been continuous declining in last few years. Many people speculate the reason behind this is the low production from farms but it is observed that the agricultural production is highest in the history and even though the position of the farmers in the economy and society is declining. This phenomenon is result of purely economic factors, the government policies are leading to suppression of agricultural business by reducing its ability to provide reliable income source. The import and export trade policies are the huge barriers in front of agricultural business and even though government has been compensating this by providing subsidies and interest free loans but its overall effect is resulting in as a major blow on the morale of farmers. In order to strengthen the agricultural business the government has to treat agricultural sector as a business and not as sacred duty to feed the population and government has to change its policies likewise.
\end{abstract}

Keywords: Agricultural Economy, Agricultural Policy, Farming, Indian Agricultural sector

\section{INTRODUCTION}

The agricultural production of the country has been increased on massive scale since1980s but the growth in the income of farmer almost negligible. This fact always contradicted by showing the income of farmers in the sugar belts but the population residing in these areas should not represent entire agricultural community. Though there is considerable increase in the production of agricultural goods, at the same time this sector is failing to support farmers economically. There was a time when dairy farming was subsidiary source of income for farmers but now roles have changed and dairy business become stable and main source of income as capacity of agricultural provide guaranteed source of income has been declined. Most of the new generations of farming families are quitting farming as they see it as a hopeless profession to choose and even the seasoned farmers encourage their children to quit farming due to uncertainties in this profession.

The desperation and pessimistic approach is not only due to the monsoon uncertainties or huge efforts and physical labor required in the farming but this desperation is mostly because of the economic problems. Even if the production of crops is good there is no guarantee of the good prices in the market. [1]
The governmental support to the agricultural sector is given through the subsidies, low interest loans and by various schemes. But this support is not even necessary if government ensure fair prices of agricultural goods. The subsidies and helping schemes gives bad impression of the farmers which is seen as the burden by government officials, metro city population and white collar class. This leads to image and moral issues of the farmers. Government officials, metro city population, upper middle class and white collar class blames farmers of economical illiteracy but they are unaware of the government control of the agricultural good pricing under the Essential Commodities Act, 1955.

This act allows governments to control the prices of the agricultural products to ensure their availability at fair prices to the general consumers. The thought behind this act is moral and logical but its wrongful implementation is the reason of the misfortune of the farmers. Government intervention in prices of agricultural goods keeps check on the inflammation but its effect on economy of farming is very devastating. [2]

Under Essential Commodities Act the prices are controlled by state and central government if prices of goods listed as essential commodities are hiked. The government keeps the prices of these good in check in case of inflammation most recent cases of this are price hike in onions (almost 100 rupees in 2014 and 80 rupees in 2017) and daal price hike (200 rupees 2017), in these cases government imported these goods from other countries to keep prices in check.

Even though in these cases very little profit is gone into the farmers pocket as these goods were already purchased by the traders but when prices onion dropped to 5 rupees in 2015 and when daal prices dropped to 25 to 30 rupees in late 2017 the export policy decisions by the government were very slow.

The government need to make policy decisions faster to ensure fair profits to the farmers and it should understand that famines, lack of finance and new technologies are no longer problems in the agricultural sector and it should focus the real economical problems of agricultural sector and it should ensure the farmer that the farming can be a stable economical source. 


\section{CHALLENGES IN FRONT OF AGRICULTURAL ECONOMY}

\section{A. Monsoon}

Famine and over rain has been problems of the agricultural but in last few decades major investments in dams, water shedding programs has been proven fruitful and dependence on monsoon for farming water has been reduced. But even though there is large agricultural land is not exposed to these kinds of projects.

\section{B. Malpractices in Trade}

Malpractices in the trade are the serious issues in the agriculture. The pesticides and fertilizers are sold at high prices than MRP and farmers cannot go to the consumer forum or to the authorities because of on paper there is no proof of this malpractice as challan is given with the price of MRP on it. And with the limited requirement, short time and very few shops available the farmer has to buy at elevated prices. The malpractices are also common while selling agricultural products, most of the traders are buying agricultural goods at low prices and then stores it for few months and when process are high then it will be sold to the consumers. The farmers cannot store their goods as it is economically not feasible for them and hence they cannot make profits.

Other malpractices like selling outdated fertilizer and pesticides, less or no distribution of government issued equipments to the farmers, faulty measuring and weighing instruments of the traders, high rates of storage and transportations are common and are completely ignored and sometimes even supported by the authorities.

\section{Labor Shortages}

Labor shortage is a problem in the agricultural sector has most of the labor population is moving towards the cities to get comfortable jobs and good lifestyle. In farming the physical labor, harsh working conditions, untimely and low pay discourage labors to work and at the same time farmers cannot compete the industrial salary and nor they can give fixed pay of specific day or date.

\section{Government Control of Trade Policies}

The Essential Commodities Act was passed in 1955 to make sure the availability of essential goods to consumer and to stop profit hungry trader from storing excessive amount of goods. The logic and philosophy behind this acts is good but implementation creates problem for the farmers. The aim of this act is to provide essential commodities to consumers at fair price and ensure income to the farmers but later part of it is often ignored.

The Act regulate and control of production, distribution and pricing of commodities which are declared as essential for maintaining supplies and availability at fair prices. This allows governments to increase the imports to drop the prices of hiked agricultural goods which is done for daal (2017) and for onion (2014 and 2017). But it is observed that government is too sensitive to control the prices of good even though they are rised even little bit above their normal prices but they are not sensible enough when prices are dropped too below the normal levels for example when daal prices are dropped below 30 rupees or onion prices are dropped below 10 rupees in 2015 government has done very little efforts to restore the prices by exporting them. For political gains sometimes governments includes commodities which are not essential like onions, cotton, and potato.[3] Onions are listed as essential commodity but from logical point of view it is not an essential commodity and farmers can be benefitted from it if its prices are hiked. But such kind of popular decisions are made for political gains.

Also agricultural produce market committees (APMC) are formed for well-being of farmers also contributing to the financial loss of farmers. The APMCs are formed to provide clean and fair trading between farmers and traders which served well to the farmers as they have got rightful channel for selling their products when private traders were few in numbers and competitive agricultural markets were absent.

Under the jurisdiction area of market committee no other organization or person can undertake the wholesale marketing. This provision is made for financial well-being of the farmers so that they can receive fair prices of their products like grains, vegetables, animals etc. but this also makes compulsion on the farmers to sell their products in these markets. APMCs also charge some additional charges for product handling, storing, processing taxes etc. These taxes vary from market committee to committee. In market committee the buyers should have licenses issued by the committee, reduces the competition for purchasing and sometimes lobbying and politics in these committees purposefully lead to reduced prices of the agricultural products. [4][5]

\section{E. Cooperative Sector}

Cooperative sector was a conceptually great solution to establish farmers as economic power in the Indian economy. The sugar factories, textile mills, dairies and other small to medium scale industries are established by farmers and which are governed by the elected representatives of farmers. This social; and economical experiment was a good success for limited period time in some part of India like Maharashtra and Karnataka but in as time passed politics, lack of management skills in elected representatives, political agendas and corruption has consumed the once powerful organizations and now they are just shadows of their past. Now only few cooperative organizations of farmers are in good conditions and others are shut down, bankrupted or on the edge of bankruptcy. 


\section{CONCLUSION}

The government import, export and trade policies are causing economical loss to the agricultural sector and due to this reliability of this sector as job and income provider has been declined considerably. Due to this most of the new generation is refusing to choose agricultural sector as carrier. The government has to revise its trade policies as well as it should change its approach towards agricultural sector and should see it as a business rather than noble duty of farmers to feed the nation without considering profit, assurance and financial stability.

\section{REFERENCES}

[1] B. Ramaswami, "Effciency and equity of food market interventions", Economic and Political Weekly, pp. 1129-1135, March 2002.

[2] Ramesh Chand, "Development Policies and Agricultural Markets", Review of Rural Affairs, Economic \& Political Weekly, Dec. 2012.

[3] Yoginder K. Alagh, "A Review on the Future of Indian Agriculture", National Book Trust, India, 2013.

[4] Ministry of Consumer Affairs, "Food and Public Distribution", Control Order Issued under Essential Commodities act 1955, Order No. 1685, July 2014.

[5] Shoumitro Chatterjee, Devesh Kapur, "Understanding Price Variation in Agricultural Commodities in India: MSP", Government Procurement, and Agriculture Markets, India Policy Forum July 1213, 2016. 